\title{
REFLECTIONS ON OFFERS AND USE OF DIGITAL MEDIA FOR TRANSFERRING KNOWLEDGE IN TEACHER EDUCATION
}

\author{
Susanne Schumacher ${ }^{1}, \&$ Ulrike Stadler-Altmann ${ }^{2}$ \\ Faculty of Education, Free University of Bozen-Bolzano (Italy)
}

\begin{abstract}
Digital processing, augmented reality and virtualisation have been developed and tested in the gaming world and working environment for some time. In educational settings, media should become learning objects that arouse the interest of learners, establish a connection to their previous knowledge, and enable interactive action and self-control (cf. Göhlich \& Zirfas, 2007; Sesink, 2008). In parallel with technological developments, the question of imparting knowledge methods as well as increasing learners' knowledge is consistently subject of debates on competence in higher education didactics (see Erhardt, 2010). In terms of knowledge theory, the question arises to which extent knowledge changes as a result of media processing and, not least, how students' knowledge assets build up, transfers and influence each other (see Stadler-Altmann \& Keiner, 2010).

In the first decade of the millennium, numerous activities introduced in higher education had been carried out related to media-based knowledge transfer and information acquisition in the context of curricular offerings, pilot events or third party financed projects with non-university cooperation partners (Iske \& Meder, 2010; Gördel at al., 2018; Hofhues, Jochuma \& Kohrs, 2013; Reinmann, Ebner \& Schön, 2013).

In this paper, concepts of media-supported teaching and learning environments in the context of the training of pedagogical professionals in South Tyrol are depicted. Didactic designs for lectures and seminars are presented and critically reflected. These two teaching formats are mainly intended for the one-level master's degree in Primary Education at the Free University of Bozen-Bolzano. The design research approach chosen for this purpose does not diminish input-output comparisons, but rather raises the question of which media-pedagogical innovations and didactic interventions can improve the existing teaching-learning situation (Fishman et al., 2013). First, the pedagogical fields of action are analysed by considering both the specific context of the given structure at university and the existing teaching-learning settings. Consequently, impulses for a didactic re-framing in the context of the methodological dimensions of control and teaching style will be discussed in the light of the current state of research.
\end{abstract}

Keywords: Digital added value, transfer of knowledge, active learning, university didactic, design research approach.

\section{Introduction}

The master's degree in Primary Education at the Free University of Bozen-Bolzano has been reformed within the Italian legislation La Buona Scuola (State Law 107/2015). The in 2017/18 relaunched degree program leads to a professional qualification in five years. Graduates will be qualified for pedagogical workers in kindergarten and primary schools and furthermore, acquire the qualification for teaching English lessons at primary school.

According to the study manifesto, in the first two years of study the focus of teaching is on the areas of Historical and Comparative Pedagogy, General Didactics, Intercultural and Inclusive Pedagogy as well as Pedagogical Psychology and Developmental Psychology, plus Linguistics (L1, L2). The third and the fourth academic year is intended for in-depth study of the respective subject didactic content. Linguistics (L3) and media pedagogy as well as didactics of early-reading instruction complete the course offerings. In the fifth year of study, elective subjects and socio-political content are discussed; furthermore, the specific institutional framework and working conditions are explained. Moreover, the master thesis is to be written in the final year of study (Study Manifesto, 2019). 


\section{Objectives and methods}

Based on the course descriptions of General Didactics information about formal details is given such as workload, attendance regulations, the lecturer's office hours as well as the objectives and topics of courses. In addition, the main teaching and learning formats are described. Lectures are tagged as weekly, with media support, partner work and short in-depth group work. In addition, preparation based on literature is expected. The labels for seminars are fortnightly, joint reading and discussion, group work, collection of material, portfolio work. Preparation and work separate the seminar are expected (Course Offerings 2019).

In a first step, the lecture is presented from a historical-systematic point of view. This is followed by a specification of the media-didactic conception of the factual class. The aspects mentioned above are assigned to conceivable resulting types of knowledge. Following the same approach, the seminar is being introduced as a learning environment with both the corresponding media-didactic interventions and the kind of knowledge that might emerge from this. Finally, the additional value of digital media for the learning environments is elaborated.

\section{Analysing lectures as pedagogical field of action}

Since the rising of universities in the 12th century, lectures have been the predominant practise of imparting knowledge (Schiewe, 2007, p. 36). The origins of this way to transfer knowledge are located at the Greek antiquity in correspondence to the current educational ideal of the time, the eu legein. By this is meant the skill of talking well about the good -as a sum of intangible entities- including not only rhetorical eloquence, but also philosophical and scientific argumentation (cf. Apel \& Koch, 1997). In Roman antiquity, public speech was developed to a discipline that could be taught and learned as well. Erler and Tornau $(2019$, p. 3$)$ point out that in teaching the art of oratory, a distinction between pragmatic routine and exact science was made; an adaptation to addressees was also taken into account. Regarding teacher training it is required both contributing actively to scientific discourse and pupil-oriented speech to lead theory-based facts into practice. Mandl \& Reinmann-Rothmeier (2006, p. 615) classifies the lecture as a system-oriented learning environment in which learning processes can be externally planned and controlled. From the perspective of educational psychology, the advantages of teacher-centred instruction are seen in the fact that both average and individual learning outcomes are higher (see Brophy \& Good, 1986). Attending lectures students are recommended to listen actively and write down crucial facts. This scheme is effective only if the essentials are understood first and then recorded. Attempting to file what literally is said tends to result in failing the core issue. From the students' point of view, echoing the transcripts is equated with responding demands and in turn, mistaken with knowledge (cf. Neubert, Reich \& Voss, 2001, p. 253). However, the idea of learning as acquisition of content is associated with an enhanced rationality.

\subsection{Concepts of media-supported interventions in the context of lectures}

University as a service provider in the education system aims to facilitate academic experiences of students, including both material resources e.g. rooms, hardware equipment or software tools and personal support for learning processes or workflows. Regarding the digital lecture hall, this means, to provide a technological infrastructure with security standards for privacy, steady and fast interoperable lines as well as compatibility to the end-users with heterogeneous operating systems of devices (see Kollmann, 2018, p. 77f). In March 2020, MS TEAMS has been set up to live stream or record lectures and seminars as well. The software solution is a platform combining various applications for classroom-management, such as chat in private or in general, tasks, forms, meetings, notes and various attachments. However, given the proper volume of technical features, neither runs teaching and learning by itself nor improves it than in presence. Looking reverse, consuming the services does not release from efforts of the learning process to build up one's own knowledge.

In preparation for the lecture, students can download a script that point out main facts of the required reading chapter (see table 1). From the didactic point of view, a summary always dissolves information units from a whole text intended for rereading, thus, reducing its complexity. Within lectures hours, it is assumed that the complexity of facts as well as dependencies on circumstances can be verbally restored. Nonetheless, problems of comprehension and understanding can only be solved at best for those present. Kade \& Seitter (2003, p. 609) argue that the mechanisms of media communication linked to presence can only refer immediately to and influence addressees. In turn, the additional value of media offered by visually prepared summaries is not applicable to those who are absent. 
Table 1. Assignment of meta-cognitive competences, deliberate media support and implementation in the teaching-learning process for lectures.

\begin{tabular}{|l|l|l|}
\hline $\begin{array}{l}\text { Meta-cognitive components to } \\
\text { accomplish the transfer of knowledge } \\
\text { from the teaching point of view }\end{array}$ & media-based support & $\begin{array}{l}\text { potentially emerging types of } \\
\text { knowledge within the learning-process }\end{array}$ \\
\hline Providing learning material. & $\begin{array}{l}\text { License-based online } \\
\text { resources such as e-books, E- } \\
\text { Journals or databases. } \\
\text { Lecture manuscripts. }\end{array}$ & $\begin{array}{l}\text { Gaining declarative knowledge by } \\
\text { exploration of the provided material. }\end{array}$ \\
\hline $\begin{array}{l}\text { Representation of facts and explanation } \\
\text { of connections. }\end{array}$ & $\begin{array}{l}\text { Animated power point slides } \\
\text { supplemented by personal } \\
\text { speech. }\end{array}$ & $\begin{array}{l}\text { Grow declarative knowledge by } \\
\text { monitoring and comprehending the } \\
\text { speech and asking questions. }\end{array}$ \\
\hline $\begin{array}{l}\text { Guiding of short time group work, } \\
\text { controlling, support and feedback. }\end{array}$ & Poster presentation. & $\begin{array}{l}\text { Increase declarative and metacognitive } \\
\text { knowledge by working deliberately on } \\
\text { tasks and discussing results. }\end{array}$ \\
\hline Highlight the systematic of knowledge. & $\begin{array}{l}\text { Animated power point slides } \\
\text { supplemented by personal } \\
\text { speech. }\end{array}$ & $\begin{array}{l}\text { Raise strategic knowledge by } \\
\text { monitoring and comprehending the } \\
\text { speech and asking questions. }\end{array}$ \\
\hline
\end{tabular}

\section{Analysis seminars as pedagogical field of action}

In the second year of study, the General Didactics puts an emphasis to approaches and results of empirical research in teaching and learning. To offer an apparent approach to transfer theory into practice, it is highly recommended to join the EduSpace Learning Workshop; at least every seminar once in the study cycle. The Learning Workshop is an open space at the first floor of the library containing material such as picture books directed to foster language learning in kindergarten as well as sensory material for the promotion of mathematical experience in elementary school (Stadler-Altmann \& Winkler, 2019). The conceptual considerations for the methodological design of all seminars point at the central question of how the materials -available in the EduSpace Learning Workshop- can be used and modified as well to bring a specific learning object easily into the learners' horizon (Schlicht, 2013). Based on the didactic concept and taking the design-oriented research approach into account, the real space of the EduSpace Learning Workshop at the one hand accomplishes a learning environment for imparting scientific generated facts, on the other hand practical knowledge for lesson planning, material development and for practicing procedural application knowledge as well (Schumacher, Emili \& Stadler-Altmann, 2019).

\subsection{Concepts of media-supported interventions in the context of seminars}

As mentioned above, learning by project planning is a guiding didactic principle of the EduSpace Learning Workshop. Learning and working in a project are closely interwoven and related to didactic-methodological features of cognitivist and even more constructivist learning theories. In the following, major paradigms of contemporary learning theories are considered in the context of their hypothesised effects on knowledge acquisition (see table 2).

Since the mid-1960s, cognitive research has increasingly focused on the processes of perception, attention, memory, and internal information processing in humans. In particular, the areas of the mental representation of knowledge have been studied as well as the processing within the construction of knowledge representations (e.g., Collins, 1987; Dennett, 1969; Stich, 1983). The results of the research from cognitive psychology serve the development of didactic theories for teaching and learning processes. According to the situated cognition perspective, learning is seen as a process of enculturation, or participation in socially organized practices, through which specialized skills are developed by the learner as they engage in an apprenticeship in thinking (Rogoff, 1990), or in legitimate peripheral participation. The 'Cognitive Flexibility Theory' by Spiro, Coulson, Feltovich \& Anderson (1988) focuses on the complexity of the learning situation and learning in multiple contexts. To grasp the complexity of a problem, it is essential to be confronted with realistic issues and furthermore, to work on the context several times from different perspectives and with different objectives. Spiro et al. consider hypermedia to be a suitable digital tool for mapping complex contexts as well as organising context under the new aspects differently. As stated by Collins et al. (1989), the key components of the apprenticeship process include modelling, coaching, scaffolding, fading, and encouraging learners to reflect on their own problem-solving strategies. This apprenticeship leads to the learner becoming involved in the authentic practices of a 'community of practice' (Lave \& Wenger, 1991). 
Table 2. Assignment of teaching strategies, media-based support and potentially emerging types of knowledge within seminars.

\begin{tabular}{|c|c|c|c|}
\hline & $\begin{array}{l}\text { Teaching strategies to enhance } \\
\text { transfer for knowledge with examples }\end{array}$ & media-based support & $\begin{array}{l}\text { potentially emerging } \\
\text { types of knowledge }\end{array}$ \\
\hline 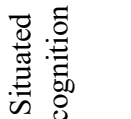 & $\begin{array}{l}\text { Analysing problems embedded in } \\
\text { theory. } \\
\text { Prepare a teaching situation. }\end{array}$ & $\begin{array}{l}\text { Tool for set up a group. } \\
\text { Chatroom: for text-based synchronous } \\
\text { discussion. }\end{array}$ & $\begin{array}{l}\text { Procedural } \\
\text { knowledge. }\end{array}$ \\
\hline 离 & $\begin{array}{l}\text { Learner conducted construction of } \\
\text { different application scenarios. } \\
\text { Collaborative creation of technical } \\
\text { features for communication (such as } \\
\text { auditory or non-electronic aids to } \\
\text { supplement text comprehension) }\end{array}$ & $\begin{array}{l}\text { stop-motion }(\mathrm{mp} 4) \text {, } \\
\text { AnyBook Reader } \\
\text { URL-links to tutorials or freeware }\end{array}$ & $\begin{array}{l}\text { Procedural and } \\
\text { conceptual } \\
\text { knowledge. }\end{array}$ \\
\hline 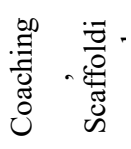 & $\begin{array}{l}\text { Developing an expert culture through } \\
\text { authentic interactions. }\end{array}$ & $\begin{array}{l}\text { Screencasts, } \\
\text { Poster presentations, } \\
\text { long-term asynchronous discussion in a } \\
\text { forum }\end{array}$ & $\begin{array}{l}\text { Metacognitive } \\
\text { processing of subject } \\
\text { content. }\end{array}$ \\
\hline
\end{tabular}

\section{Conclusion}

Media-based teaching strategies and its expected knowledge types were portrayed for lectures and for seminars. To conclude, if media-based lectures and seminars continue the model of centrally controlled instruction aligned to traditional structures and practices, like content focused outcomes or rather declarative knowledge. The central mode in which learning happens there is memorisation. However, reproductive learning contains a certain productive moment, which is a preliminary stage of discursive learning in terms of knowledge methodology. Preferably, learning takes place oscillating between the overarching teaching-learning discourse of the lecture and the discourse in the seminars (cf. Ehlich, 2014). Great coherence within the scientific domain is of advantage because it's getting visible more than ever.

Digital tools, such as screencasts provide a closer insight into the learning process or rather the knowledge construction. This result from the fact that single steps of the task responses are transparently linked, therefore learning moments can be tracked back to the pedagogical intervention even better. Learning in these contexts shifts the boundary from known to unknown knowledge. While inquiry learning is still oriented towards teaching knowledge, productive learning represents a qualitative advance in that learning research knowledge is now integrated. In this way, the threshold towards emancipation from institutional teaching-learning discourses can be approached.

In general, pedagogical teaching-learning environments are characterised by a material offer of opportunities for connection, acquisition and communication. If these facilities are mono-functional, existing structures are maintained. The situation is different with multi-functional spaces. Thinking about hybrid spaces means to consider differentiated and individual learning in advance.

\section{References}

Apel, H.-J. \& Koch, L. (1997). Überzeugende Rede und pädagogische Wirkung. Zur Bedeutung traditioneller Rhetorik für pädagogische Theorie und Praxis. Weinheim: Juventa.

Brophy, J. E., \& Good, T. L. (1986). Teacher behavior and student achievement. In M. C. Wittrock (Ed.), Handbook of Research on Teaching, (pp. 376-391). New York, NY: Macmillan.

Collins, A., (1987). The Nature of Mental Things, Notre Dame: Notre Dame University Press.

Collins, A., Braun, J.S. \& Newman, S.E. (1989). Cognitive Apprenticeship: Teaching the Crafts of Reading, Writing and Mathematics. In L. B. Resnick (ed.), Knowing, Learning and Instruction. Essays in Honour of Robert Glaser. (pp. 453-494). Hillsdale, NJ.

Course Offerings (2019). Retrieved Jan. 30, 2021 from https://www.unibz.it/de/faculties/ education/master-primary-education/course-offering/

Dennett, D. (1969). Content and Consciousness, London: Routledge \& Kegan Paul.

Ehlich, K. (2014). Argumentieren als sprachliche Ressource des diskursiven Lernens. In A. Hornung, G. Carobbio \& D. Sorrentino (eds.): Diskursive und textuelle Strukturen in der Hochschuldidaktik. Deutsch und Italienisch im Vergleich, (pp. 41-54). Münster: Waxmann.

Erhardt, U. (ed.). (2010). Neue Impulse in der Hochschuldidaktik. Sprach- und Literaturwissenschaften. Wiesbaden: Springer. 
Fishman, B. J.; Penuel, W. R.; Allen, A. R. \& Cheng, B. H. (eds.) (2013). Design-Based Implementation Research: Theories, Methods, and Exemplars. National Society for the Study of Education. The 112th Yearbook. Issue 2. New York: Columbia University.

Göhlich, H.D. M. \& Zirfas, J. (2007). Lernen. Ein pädagogischer Grundbegriff. Stuttgart: Kohlhammer

Gördel, B.-M.; Schumacher, S. \& Stadler-Altmann, U. (2018). Durch digitale Medien gestützte Seminarformen. Zwischen dem Anspruch technologisch zeitgemäßer Wissensvermittlung und pädagogisch angemessener Lernumgebung. In J. Othmer, A. Weich \& K. Zwickwolf (eds.), Medien, Bildung und Wissen in der Hochschule, (pp. 99-113). Wiesbaden: Springer.

Hasselhorn, M. \& Gold, A. (2009). Pädagogische Psychologie: Erfolgreiches Lernen und Lehren. Stuttgart: Kohlhammer.

Hofhues, S., Jochums, A.-S. \& Kohrs, L. M. (2013). Vielfalt der Medien, Komplexität medialer Bildungsräume? Gestaltung und Erforschung crossmedial-vernetzter Medienprojekte an Hochschulen. medien + erziehung (merz) Wissenschaft 6/2013, pp. 108-119.

Iske, S. \& Meder, N. (2010). Lernprozesse als Performanz von Bildung in den Neuen Medien. In K.U. Hugger \& M. Walber (eds.), Digitale Lernwelten. VS Verlag für Sozialwissenschaften

Kade, J. \& Seitter, W. (2003). Von der Wissensvermittlung zur pädagogischen Kommunikation, Theoretische Perspektiven und empirische Befunde. Zeitschrift für Erziehungswissenschaft, 4/2003, pp. 602-617.

Kollmann, F. (2018). Technologische Unterstützung der Wissensvermittlung in Vorlesungen: informatische Entwicklung und empirische Erforschung der Wirkung und Wirksamkeit digitaler Lernobjekte. Retrieved Feb. 20, 2021 from http://dokumentix.ub.unisiegen.de/opus/volltexte/2018/1313/

Lave, J. \& Wenger, E. (1991). Situared learning. Legitimate peripheral participation. Cambridge: University Press

Neubert, S., Reich, K. \& Voß, R. (2001). Lernen als konstruktiver Prozess. In T. Hug (Ed.), Die Wissenschaft und ihr Wissen, Bd. 1. Baltmannsweiler: Schneider Verlag Hohengehren

Reinmann, G., Ebner, M. \& Schön, S. (eds.) (2013). Hochschuldidaktik im Zeichen von Heterogenität und Vielfalt. Doppelfestschrift für Peter Baumgartner und Rolf Schulmeister. Retrieved April. 20, 2021 from http://bimsev.de/n/userfiles/downloads/festschrift.pdf

Rogoff, B. (1990). Apprenticeship in Thinking. Cognitive Development in Social Context. Oxford University Press, New York,

Schiewe, J. (2007). Zum Wandel des Wissenschaftsdiskurses in Deutschland. In P. Auer \& H. Baßler (Eds.), Reden und Schreiben in der Wissenschaft. Frankfurt a.M./New York: Campus, 2007, pp. 31-49

Schumacher, S.; Emili E. A. \& Stadler-Altmann, U. (2019). Effective Learning Experiences with UDL in teacher training at University. Richerche di Pedagogia e didattica. Journal of Theories and research in education. Bologna: OpenJournal. Retrieved April 4, 2021 from https://rpd.unibo.it/article/view/8483

Sesink W. (2008). Bildungstheorie und Medienpädagogik. Versuch eines Brückenschlags. In J. Fromme \& Sesink W. (eds.), Pädagogische Medientheorie. VS Verlag für Sozialwissenschaften.

Spiro, R. J., Coulson, R. L., Feltovich, P. J., \& Anderson, D. K. (1988). Cognitive flexibility theory advanced knowledge acquisition in ill-structured domains, Technical Report No. 441. University of Illinois at Urbana-Champaign, pp. 1-20.

Stadler-Altmann, U. \& Keiner, E. (2010). The persuasive power of figures and the aesthetics of the dirty backyards of statistics in educational research. In P. Smeyers \& M. Depaepe (eds.), Educational Research, 1, Vol. 5, Educational Research - the Ethics Aesthetics of Statistics (pp. 129-144). Wiesbaden: Springer.

Stadler-Altmann, U. \& Winkler, G. (2019). Aus zwei Orten wird ein Lernraum. Transformationsprozesse inhaltsbezogener Raumgestaltung - die Kooperation zwischen Universitätsbibliothek und EduSpace Lernwerkstatt, In S. Tänzer, G. Mannhaupt, M. Berger \& M. Godau (eds.), Lernwerkstätten im Spannungsverhältnis zwischen Individuum, Gemeinschaft, Ding und Raum, Bad Heilbrunn: Klinkhardt.

State Law 107 (2015). Retrieved April 20, 2021 from http://www.paschinimarchi.it/legge-107-del-13luglio-2015-riforma-della-scuola-con-note.pdf

Stich, S. (1983). From Folk Psychology to Cognitive Science, Cambridge, Mass.: The MIT Press.

Study Manifesto (2019). Retrieved January 28, 2021 from https://www.unibz.it/assets/Documents/StudyManifestos/2019/Manifesto-2019-02-27-Master-Primary-Education-LM85bis-de.pdf

Tornau, Chr. \& Erler, M. (2019). Sachregister. In Chr. Tornau \& M. Erler (eds.), Handbuch Antike Rhetorik (pp. 801-810). Berlin: De Gruyter. 